\title{
Multi-Scalar Mapping of Potential Voters in Tunisia's 2019 Presidential Elections
}

\author{
Mongi Belarem ${ }^{1,2}$ \\ ${ }^{1}$ Department of Geography and GIS, Faculty of Humanities and Arts, King Abdulaziz University, Jeddah, KSA \\ ${ }^{2}$ Syfacte Research Laboratory, Department of Geography, Faculty of Humanities and Arts, University of Sfax, ATCIG, Sfax, Tunisia \\ Email: aremmongi@yahoo.fr
}

How to cite this paper: Belarem, $M$ (2020). Multi-Scalar Mapping of Potential Voters in Tunisia's 2019 Presidential Elections. Open Journal of Political Science, 10, 27-40.

https://doi.org/10.4236/ojps.2020.101003

Received: October 30, 2019

Accepted: December 13, 2019

Published: December 16, 2019

Copyright (c) 2020 by author(s) and Scientific Research Publishing Inc. This work is licensed under the Creative Commons Attribution International License (CC BY 4.0).

http://creativecommons.org/licenses/by/4.0/

(c) (i) Open Access

\begin{abstract}
In Tunisia, and after the 2011 revolution, the electoral potential increased between 2011, 2014, 2017, 2018 and 2019. Similarly, the structure of this potential, by age and sex, has evolved during these different periods. During the 2019 presidential and legislative elections, 6,620,983 people were registered to vote within Tunisia (www.isie.tn). The structure of this electoral potential deserves to be mapped and analysed on different scales. In this study and using the Hyperatlas software, we have mapped and analyzed the Tunisian electoral potential for 2019, by sex and age group. HyperAtlas is a means of multiscale analysis. It is a "tool for measuring and mapping territorial inequalities" (Ysebaert et al., 2011). After the creation of the registration database for elections, we were able to visualize and analyse the inequalities in distribution and structures between the three regions (North, Central and South), the six sub-regions (NE, NO, CE, CO, SE and SO), the 24 governorates of the territory and the 275 delegations of the country, on the one hand, and between the different units on the other hand.
\end{abstract}

\section{Keywords}

Multi-Scalar Mapping, Presidential Elections, Potential Voters, Tunisia

\section{Introduction}

Since 2011, Tunisia has had several parliamentary, presidential and communal elections. Generally, the number of registrants, in Tunisia and abroad, varies between the various elections. During the 2019 presidential and legislative elections, 6,620,983 people were registered vote inside the Tunisian territory (www.isie.tn). The potential of voters within the country has increased between 
2011, 2014, 2017, 2018 and 2019. Similarly, the structure of this potential, by age and sex, has changed during these different periods. This structure deserves to be mapped and analysed according to different scales.

In this study, we used the Hyperatlas software to map and analyze the Tunisian electoral potential of 2019 on different scales. We also analyzed this potential by sex and age group.

This study consists of three parts. The first part is introductory, in which we have described the methodology of the work and we have also presented the software and the data used. In the second part, we studied the potential of electors at different scales, by sex and by age group. Finally and in the third part, we presented some summary elements and some recommendations.

\section{Presentation of the Study Area and Methodological Elements}

\subsection{The Study Area}

Tunisia is subdivided into three major zones: the North, the Centre and the South. Each zone comprises two regions: the North East, the North West, the Central East, the Central West, the South East and the South West. Each region is composed of $\mathrm{x}$ number of governorates. The whole territory is composed of 24 governorates. Each governorate has an X number of delegations. There are 275 delegations across the country (Dhieb \& Belarem, 2016; Dhieb et al., 2015). In this study, we use four scales of analysis; the zone, the region, the governorate and the delegation (Figure 1 and Figure 2).

\subsection{The Data Used}

We used the registration data for the elections. They are extracted on the web

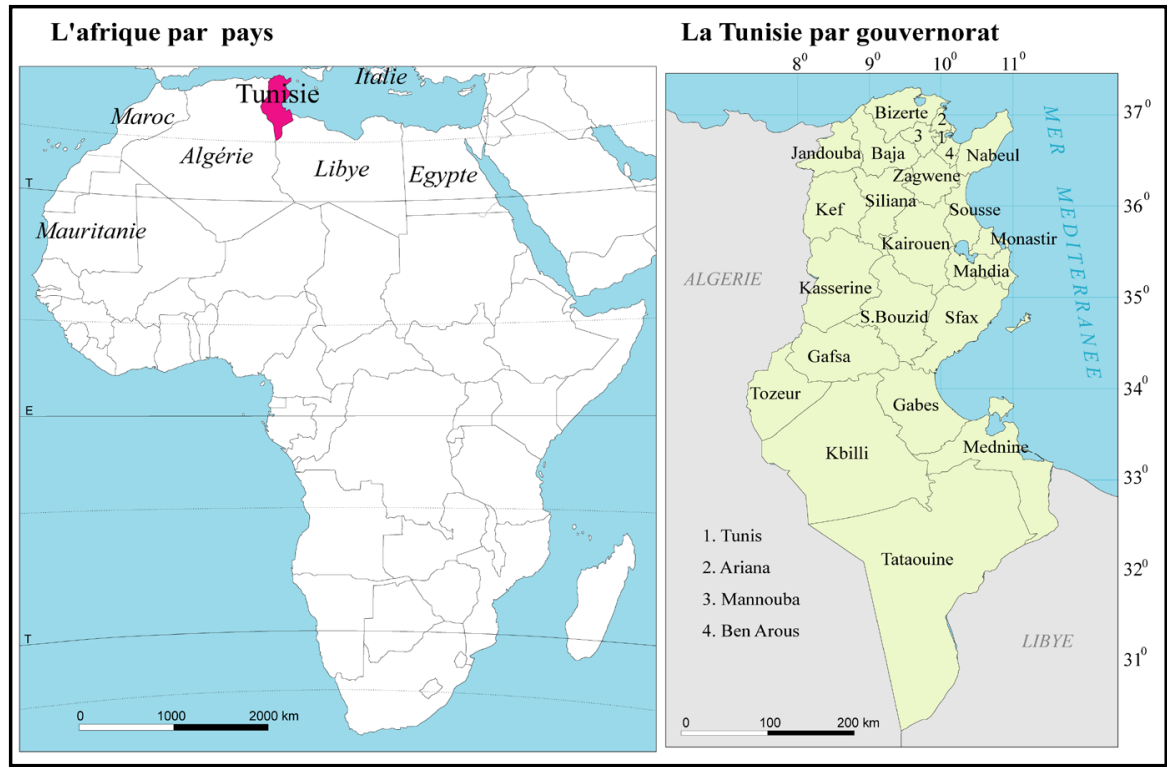

Figure 1. Study area (source: Ben Fguira \& Belarem, 2018). 


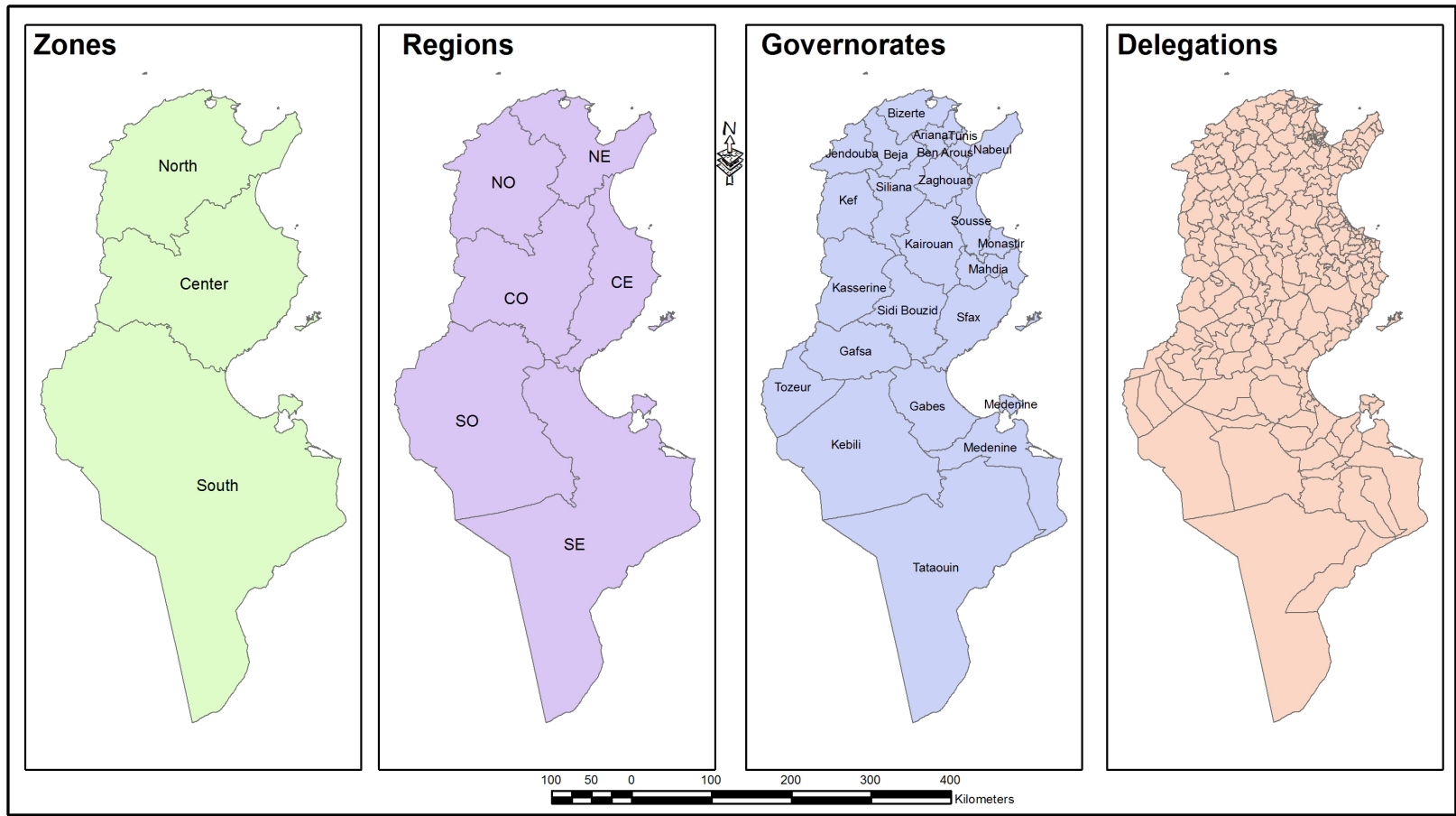

Figure 2. The scales of mapping and analysis of electoral data.

from the Independent Higher Authority of Elections I.H.A.E. (www.isie.tn). Population data are extracted from the website of National Institute of Statistics N.I.S. (www.ins.nat.tn). We used the 2014 Census of Population and Housing. This census is used by the I.H.A.E., to prepare and verify the list of potential voters. In addition to these two main sources, we use other previous studies (Belarem, 2017; Gana \& Van Hamme, 2016; Gana et al., 2012; Gana, 2011; Belhedi, 1992a, 1992b, 2005; Franklin et al., 1992a; Franklin, 1992b; Delwit, 2019; http://hypercarte.imag.fr; https://en.wikipedia.org).

\subsection{Methodology and Software Used}

This work is based on the fruit on cooperation between the teams of researchers at the CNRS RIATE (UMS 2414), Géographie-cités (UMS 8504) and the SYFACTE research laboratory at the University of Sfax. In fact, this cooperation produced a Tunisian socio-economic hyperatlas. We used the data and map background files of this HyperAtlas, after making the necessary modifications, to create an electoral HyperAtlas.

We used the Excel software to process and organize statistical data. Two tables are provided: the first is that of structure. It is composed of several sheets "respecting a defined model" (Benoit Le, 2011). In the second file, we introduced the inventory data for the elections. The ratio type data will be generated automatically by HyperAtlas.

We also used a MID/MIF file that includes the geometric description of the spatial units. This file is generated under the Mapinfo software, after the creation of the vector map background. 
We have integrated the three geometry, inventory and structure files into the HyperAdmin software. The generated product is a HyperCarte extension file (.hyp). This file can be opened and manipulated on the HyperAtlas software for the generation of maps and cartographic reports. HyperAtlas is an embossed multi-scalar analysis tool. It is "a tool for measuring and mapping territorial inequalities” (Figure 3) (Ysebaert et al., 2011; Benoit Le, 2011).

\section{Mapping and Analyzing the Potential of Voters}

Following the creation of the registration database, we were able to visualize and analyze the inequalities in the distribution of population and registrants for elections between the three regions (North, Central and South), the six sub-regions (NE, NO, CE, CO, SE and SO), the country's 24 governorates and 275 delegations, on the one hand (Belarem, 2017), and between the different units of the different scales on the other. Hyperatlas offers the advantage of comparing different spatial units of the same scale, and of comparing one spatial unit with other units of different scales.

In the following paragraphs, we map and analyze the spatial distribution of electors, the ratio of registrants and the overall population, and the structure of registrants by age and sex.

\subsection{Spatial Distribution of Population and Registrants for the 2019 Elections}

Maps A1, A2, A3 and A4 show the distribution of the Tunisian population, according to the different scales of analysis. Moving from small to large scale, the spatial distribution of the population becomes more detailed.

In the A4 map we see a concentration of population in delegations of the eastern coast of the country. Map A3 shows that the most populous governorates are in the eastern part of the country. Several reasons explain this phenomenon. Among these factors, we can mention that the east coast of the country is a plain or concentrates most industrial and tertiary activities and job offers (Chouari \& Belarem, 2016).

Map B4 shows the distribution of registrants by delegation. It is noted that

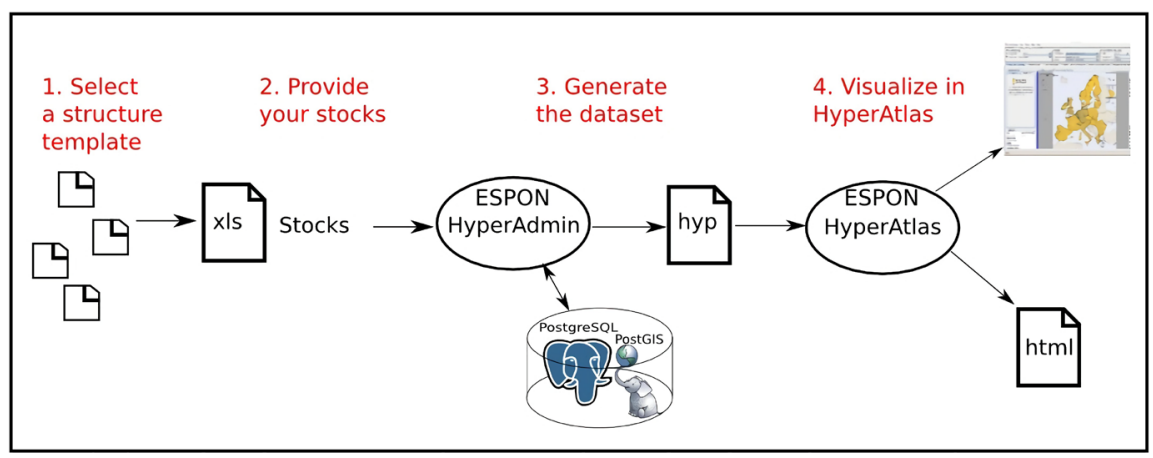

Figure 3. Map generation process with HyperAdmin and HyperAtlas (Source: http://hypercarte.imag.fr/). 
there is a cleavage between the coast and the interior of the country, in number of registered. Maps B1, B2, B3, and B4 are almost identical to those of the population (Figure 4(a). maps A1, A2, A3 and A4). The number of registrants is therefore proportional to the number of people.

The coastal areas monopolize almost three-quarters of the population. But even in the coastal zone, the difference in the distribution of registrants is very remarkable. The three major urban centers; the Greater Tunis, the Greater Sfax and Sousse take over the majority of the registrants. In these three population basins, the largest number of registered workers is recorded.

The coastal areas monopolize almost three quarters of the population (Table 1; Figure 4(b)). But even at the level of the littoral zone, the difference of distribution of the registrants is very remarkable. The three major urban centers; Greater Tunis, Grand Sfax and Sousse capture the majority of participants. In these three population basins, the number of the largest registrants is recorded (Figure 4 and Figure 5).

\subsection{Spatial Distribution of Registration Rates for the 2019 Elections}

The registration rate is the ratio of the number of registrants for elections to the total population. It is generated automatically by HyperAtlas. This rate is represented by the four mapping scales (zone, region, governorate and delegation) in Figure 6. This figure shows the registration rate in the parliamentary

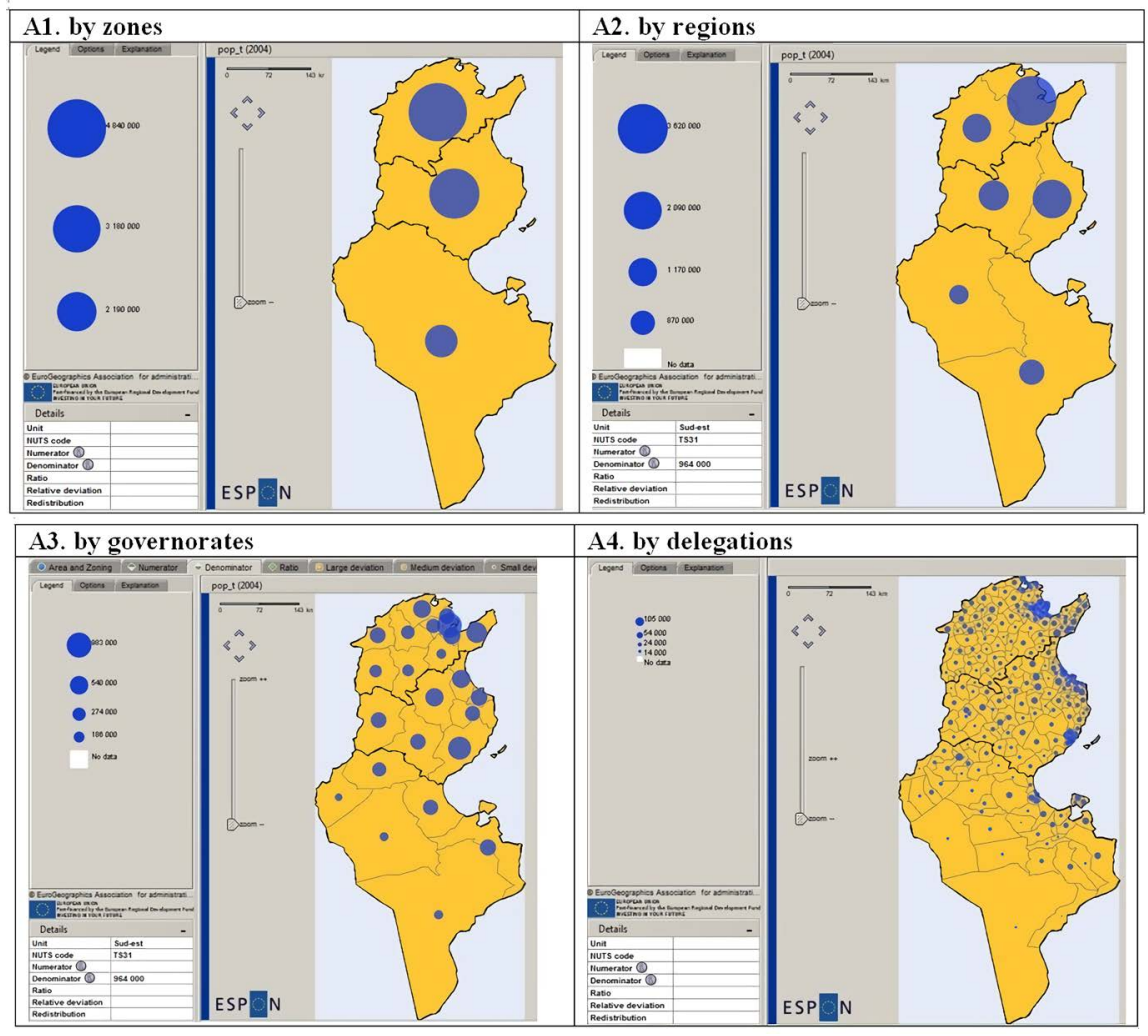

(a) 


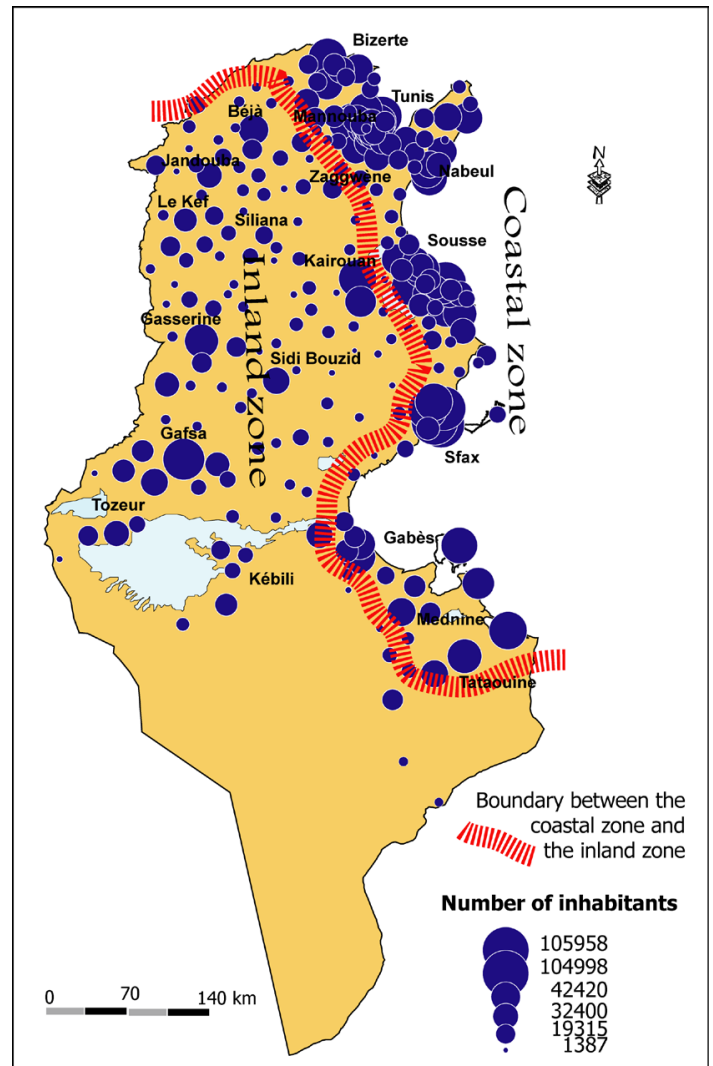

(b)

Figure 4. (a) Population distribution in 2014; (b) Population distribution by cities (the inner/coastal cleavage) in 2014.

Table 1. Population by governorate in 2018 (www.ins.nat.tn).

\begin{tabular}{cccc}
\hline Coastal or eastern governorate & Population & Western governorate & Population \\
\hline Tunis & $1,071,375$ & Kef & 246,602 \\
Ariana & 642,511 & Siliana & 227,264 \\
Ben Arous & 691,113 & Kaurouen & 589,481 \\
Mannouba & 410,104 & Kasserine & 455,193 \\
Nabeul & 843,220 & Sidi Bouzid & 449,026 \\
Zagwene & 186,210 & Gafsa & 349,385 \\
Bizerte & 589,342 & Tozeur & 113,444 \\
Baja & 306,913 & Gbelli & 166,260 \\
Jendouba & 403,930 & Total of Western gov. & $\mathbf{2 , 5 9 6 , 6 5 5}$ \\
Sousse & 726,867 & \% of Western gov. & $\mathbf{2 2 . 4 8}$ \\
Monastir & 589,683 & & \\
Mahdia & 435,296 & & \\
Sfax & $1,004,042$ & & \\
Gabes & 395,755 & & \\
Mednine & 507,673 & & \\
Tataouine & 150,761 & & \\
\% of Coastal or Eastern gov. & $\mathbf{8 , 9 5 4 , 7 9 2}$ & & \\
\hline
\end{tabular}




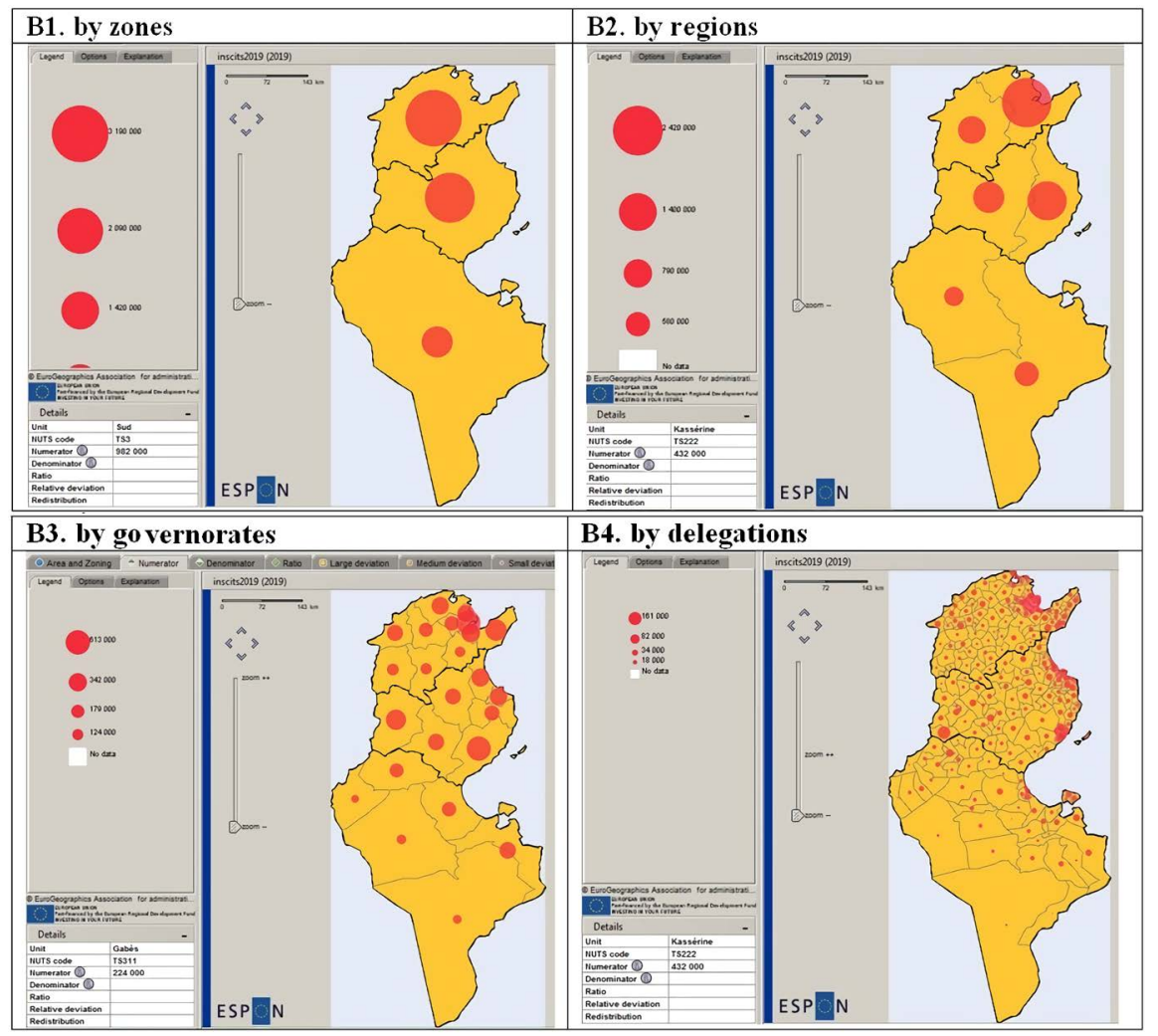

Figure 5. Registrants for the 2019 parliamentary and presidential elections.

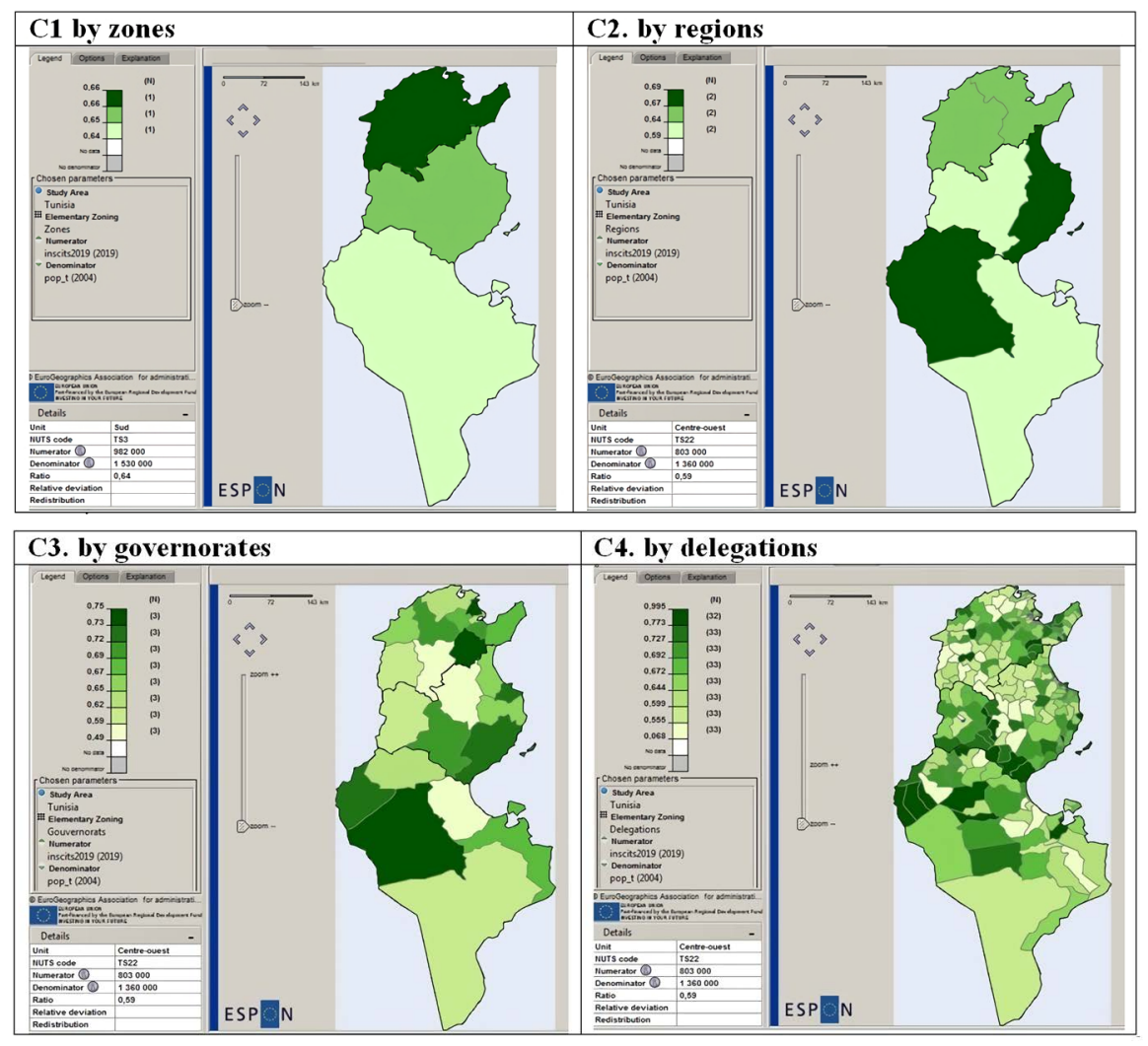

Figure 6. Voter turnout for parliamentary and presidential elections. 
and presidential elections. In this figure, we used the degradation of green color. The dark green indicates that participation rates are high. However, light green is used for low rates. Moving from the $\mathrm{C} 1$ map to the $\mathrm{C} 4$, we notice the growth in detail levels. The $\mathrm{C} 4$ map offers much more detail than the $\mathrm{C} 1$ map.

At the zone level, the highest rate is recorded in the North. At the level of the six regions, the highest rates are recorded in the Central East and South West.

At the governorate level, it can be seen that, generally, the governorates of the North East, the Sahel and the South West have higher values. The variability of rates is very clear at the delegation level. The highest rates are recorded in the West Central, North East and South West delegations.

Registration rates are not correlated with population. They are, generally, related to other factors such as, for example, the awareness role of people through the ISIE and the mass media, to register. Bringing the registration service closer to the residents is also a very important factor. This is the role of the ISIE.

Map D1 (Figure 7) "proposes a relative perspective of the distribution of the ratio (numerator/denominator) over the units of the elementary zoning: each absolute measure is related to its medium context reference value. The index value is 100 when an elementary unit has exactly the same value than its reference unit. It is 200 when the elementary unit measure is twice the reference one it is 50 when

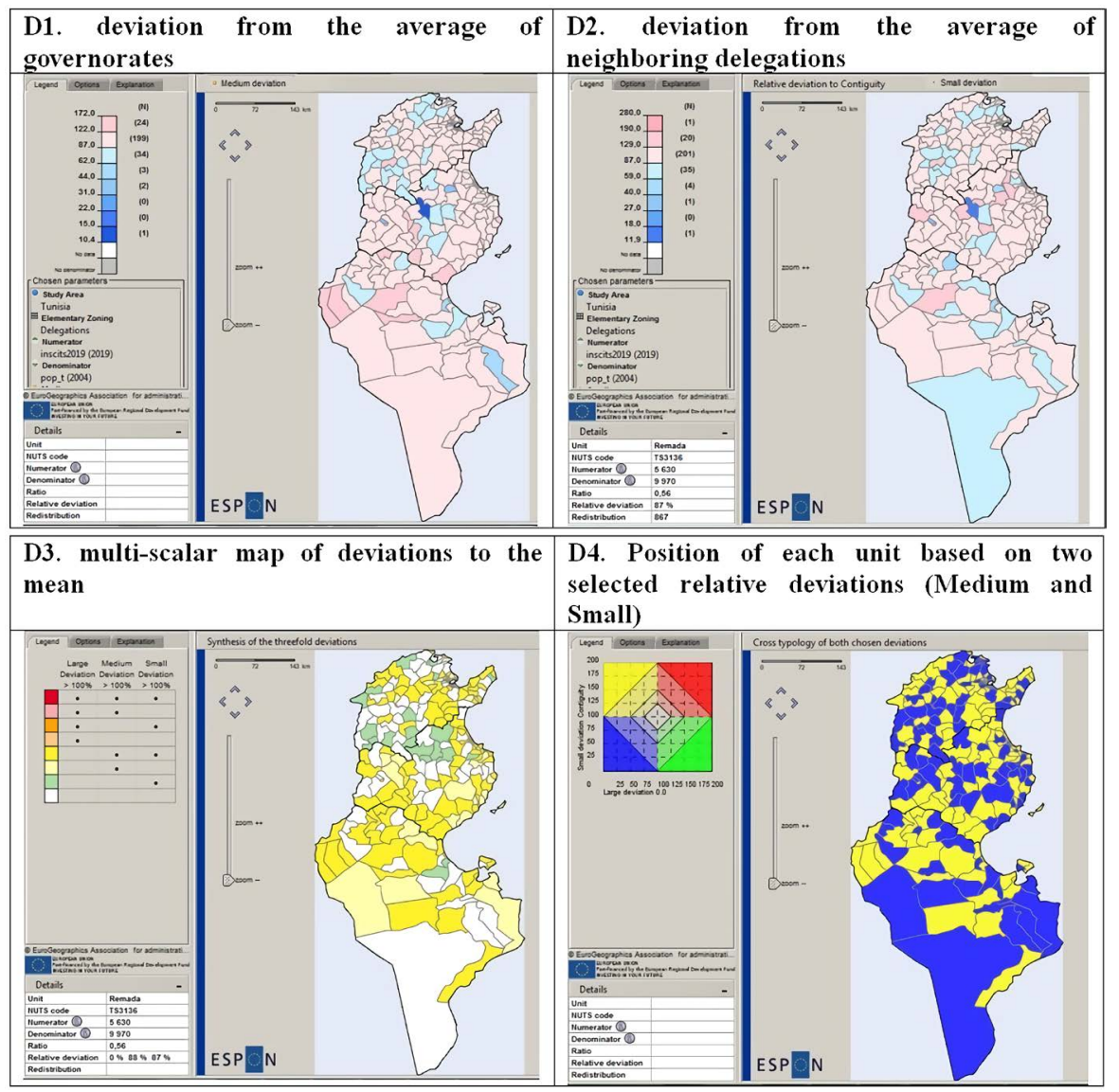

Figure 7. Voter registration rate: summary of variations. 
this is half the reference unit" (http://hypercarte.imag.fr/hypercarte_userManual). Delegations colored in pink (degraded) have higher registration rates than the average of the rates recorded at the governorate levels. On the other hand, the spatial units, colored in gradient of blue, have registration rates lower than the average of the rates recorded in all the governorates.

Map D2 "proposes a relative perspective of the distribution of the ratio (numerator/denominator) over the units of the elementary zoning: each absolute measure is related to its small context reference value" (http://hypercarte.imag.fr/hypercarte_userManual). The pink colored space unit has a higher registration rate than the neighboring delegation. On the other hand, the unit colored in blue has a registration rate higher than the rate recorded in its neighborhood (Figure 7).

Map D3 "proposes a synthesis of the different perspectives according to the threefold large, medium and small and spatial contexts"

(http://hypercarte.imag.fr/hypercarte_userManual). "Its reading is more delicate and it is difficult to deduce a strong spatial structure" (Beauguitte \& Lambert, 2015)

Map D4 "of chromatic diamond synthesis provides the position of each unit according to two chosen relative deviations. The color defines the qualitative situation of a region below/above the mean for both criteria. The intensity (color saturation) of the color defines the quantitative situation of the unit according to the criterion of common/exceptional values of deviations on both criteria" (http://hypercarte.imag.fr/hypercarte_userManual).

Map 4 shows, first of all, the delegations in which average behavior occurs: the registration rate is not higher than the national average, nor the average of the governorates, nor that of the neighboring delegations. On the contrary, the delegations in red indicate those where the enrolment rate is higher than the country average, the average of the governorates and those of neighboring delegations (Figure 7) (Beauguitte \& Lambert, 2015). "This tool makes it possible to perceive studied behaviors by highlighting ordinary individuals and remarkable individuals from a multiscalar point of view" (Beauguitte \& Lambert, 2015).

\subsection{Distribution of Registrants for the 2019 Elections by Age and Sex}

Insofar as the structure of registrants differs from that of voters and can explain it, even in part, it is useful to apprehend it here. We have mapped this structure by sex and by age groups.

\subsubsection{Distribution of Registrants by Sex}

Generally, registration rates for men are slightly higher than those of women, with small spatial variations between different spatial units, regardless of the scale of analysis.

Figure 8 shows that registration rates for men and women exceed $50 \%$ in most governorates. In Sfax, Gabès and Mednine, women's registration rates are 


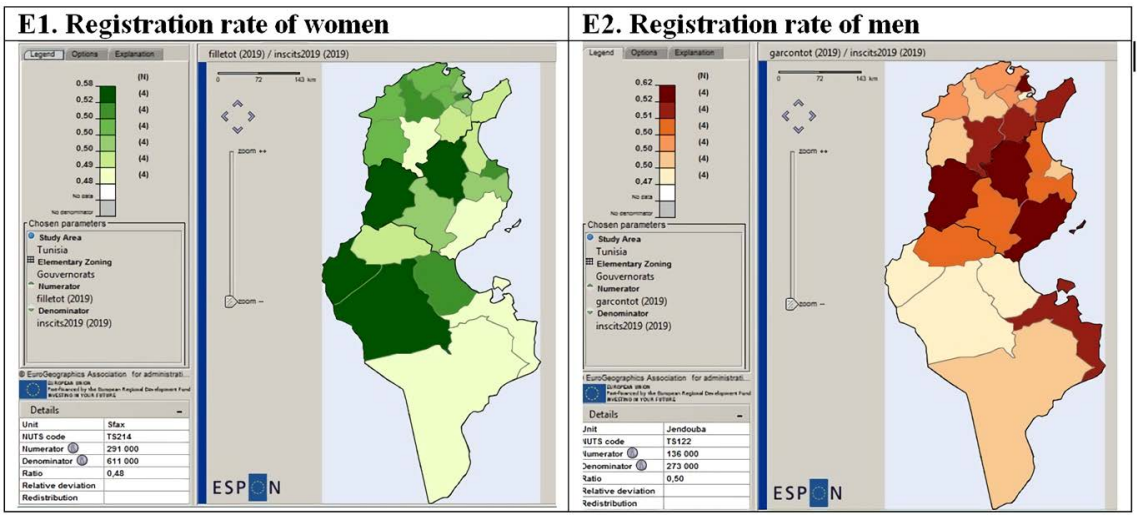

Figure 8. Distribution of registration rates by sex and governorate for the 2019 elections.

slightly below 50\%. They exceed 55\% in the governorates of Gbelli, Tozeur, Kassenine and Kairouen, but without reaching $60 \%$. Among men, the highest rates exceed 54\%, are recorded in Ariana, Sfax, Kasserine and Kairouen, where the rate reaches $62 \%$. The lowest rates are recorded in the South, in the governorates of Gabes, Tozeur and Gbelli where the rate is $47 \%$.

\subsubsection{Distribution of Registrants by Age Group}

According to the N.I.S. census, the total population is of the order of $9,910,872$ inhabitants. The total number of registrants for the 2019 elections, within the country, is $6,620,983.50 .5 \%$ of registrants are men $(334,542)$, and $49.5 \%$ are women $(3,251,441)$. The I.H.A.E. disseminated enrolment statistics by sex and by four age groups; between 18 and 25, between 26 and 45, between 46 and 60 and over 60 (Figure 9 and Table 2).

The share of registrants (men and women) in the first age group $18-25$ is $14 \%$. The second age group ( $26-45)$ represents $49 \%$. The registrants of the third group ( 46 - 60 years) define $25 \%$. Finally, the age group, that is to say those who have exceeded 60 , defines $17.76 \%$.

The largest share of women (43.98\% of all registrants) is in the $26-45$ age group. They are of the order of $1,471,516$. Those, who are between 45 and 60 years old, define $(24.44 \%)$ of all registrants. Women of the third age are of the order of 531,724 . They define $16.23 \%$. Finally, the youngest women (between the ages of 19 and 25) are in fourth place, with $13.7 \%$ of all registered (Figure 9 and Table 2).

The largest proportion of registered men (41.82\%) is in the 26 - 45 age group. They count $1,399,375$. Those in the $45-60$ age group are in second place, and represent $25.34 \%$ of registered men. The registered seniors define $17.67 \%$. Finally the youngest (between 18 and 25 years), are of the order of 458,710. They define $13.70 \%$ (Figure 10).

The spatial distribution of registrants shows that the share of women in the first tranche (18 - 25 years) is higher (16\%) in the governorates of Kairouen, Kasserine, Monastir and Tataouine, than in the other governorates. On the other hand, their share is decreasing in Tunis, Ariana, Ben Arous and Kébilli. 


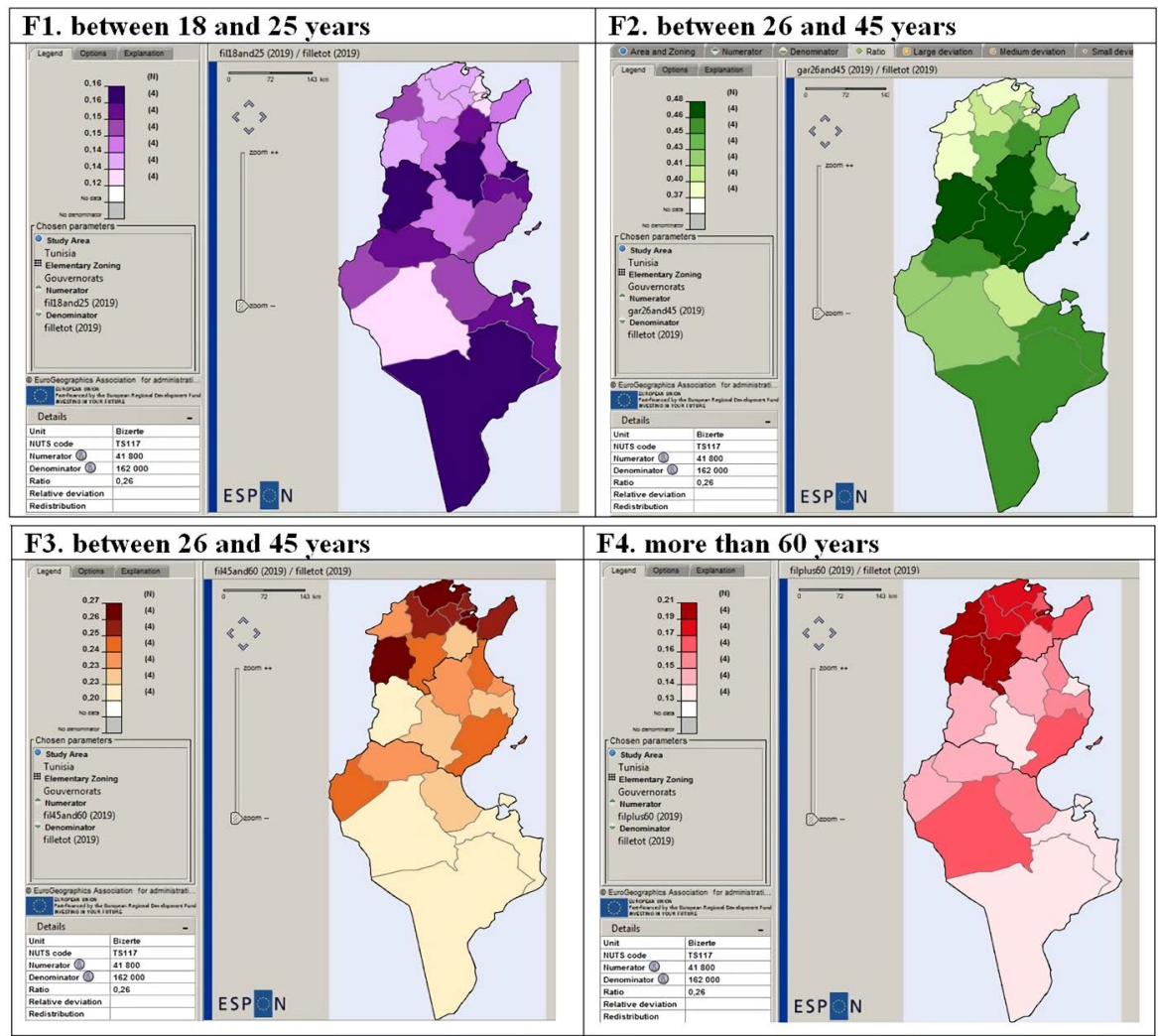

Figure 9. Rates of women registered for elections by age group.

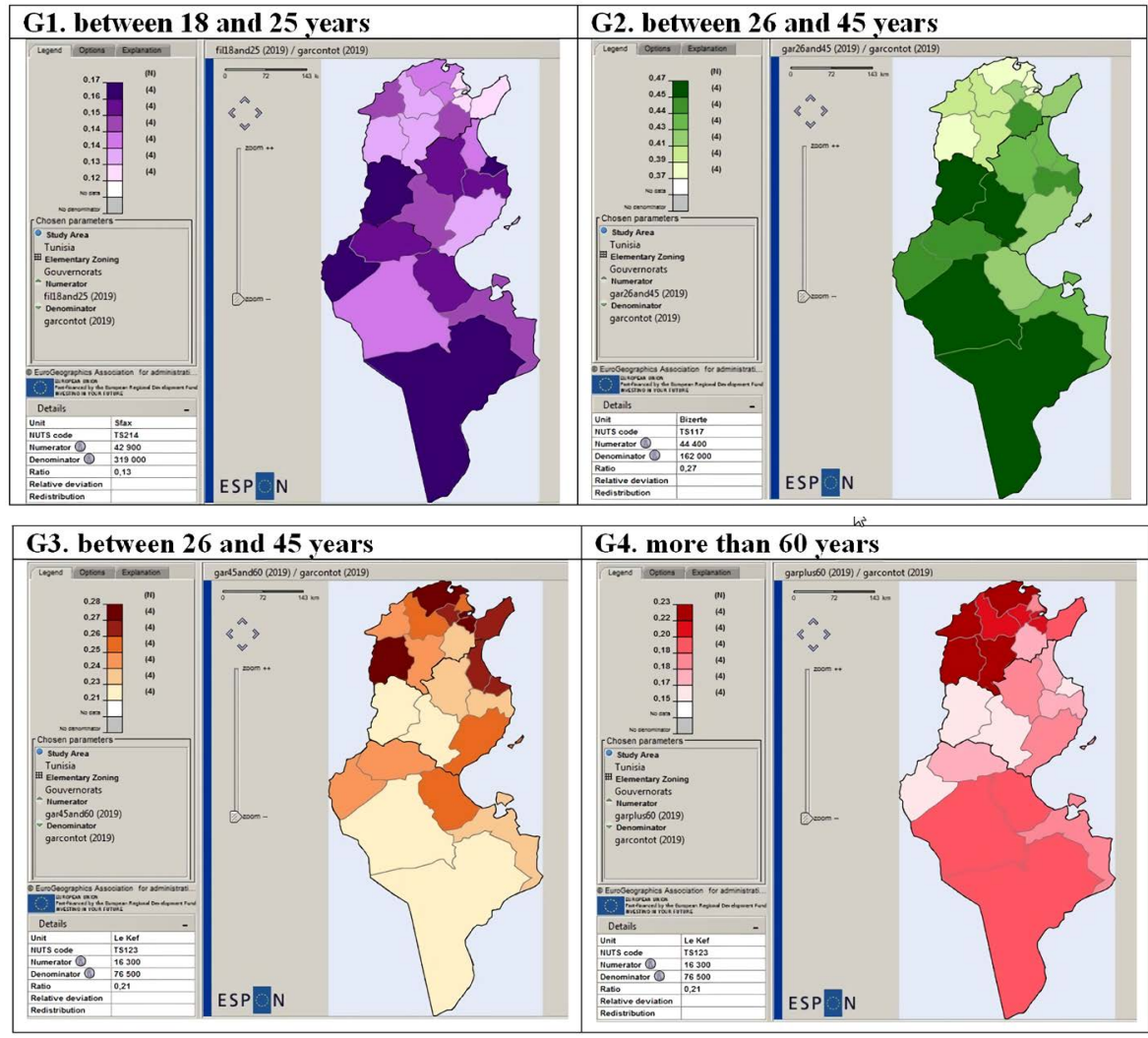

Figure 10. Male registration rates for elections by age group. 
Table 2. Distribution of registration by sex and governorate for the 2019 elections (www.isie.tn).

\begin{tabular}{cccccc}
\hline Governorate & $\begin{array}{c}\text { registration } \\
\text { rate of women }\end{array}$ & $\begin{array}{c}\text { registration } \\
\text { rate of men }\end{array}$ & Governorate & $\begin{array}{c}\text { registration } \\
\text { rate of women }\end{array}$ & $\begin{array}{c}\text { registration } \\
\text { rate of men }\end{array}$ \\
\hline Tunis & 49 & 51 & Monastir & 50 & 51 \\
Ariana & 54 & 50 & Mahdia & 50 & 50 \\
Ben Arous & 50 & 50 & Sfax & 52 & 48 \\
Manubah & 50 & 50 & Kairouan & 62 & 58 \\
Nabeul & 51 & 49 & Kasserine & 58 & 56 \\
Zaghouan & 51 & 49 & Sidi Bouzid & 51 & 50 \\
Bizerte & 50 & 50 & Gabes & 49 & 51 \\
Beja & 50 & 50 & Medenine & 52 & 48 \\
Jendouba & 50 & 50 & Tataouine & 50 & 49 \\
Le Kef & 50 & 50 & Gafsa & 51 & 49 \\
Siliana & 52 & 48 & Tozeur & 48 & 52 \\
Sousse & 51 & 49 & Kebili & 47 & 53 \\
\hline
\end{tabular}

It is only $12 \%$ in Kebilli. The share of women of the second age group (26 45 ) exceeds $46 \%$ in some central governorates (Sfax, Sidi Bouzid, Kairouen and Kasseirne). On the other hand, it is decreasing in three northern governorates (Kef, Siliana and Bizerte) and in Gabès. The proportion of women in the third age group (46 - 60) is decreasing almost gradually from North to South (from $25 \%$ in the North to $16 \%$ in the South). Finally, the share of women in the last age group, that is to say, those who have passed the age of 60 , is decreasing according to a North (21\%) - South (12\%) gradient (Figure 10).

\section{Conclusion and Recommendations}

Based on this study, it is understood that multi-scale mapping is a tool for analyzing and visualizing data using different scales. Applied to the Tunisian electoral potential, this method allowed us to compare the position of each spatial unit with other neighborhood units of the same level, and with other units of another level. It was found that modifying the analysis scale was effective and allowed for spatial variations in registrant rates. We can also note that:

- The total number of registrants for the 2019 elections, within the country, is $6,620,983 ; 334,542$ registrants are men and 3,251,441 are women.

- Multiscalar analysis shows that there are spatial disparities between the different levels of analysis, and generally the smaller the spatial unit, the greater the level of detail.

- The largest share of registrants exists in the coastal area.

- There are no major differences in the distribution of registrants by sex. $49.5 \%$ of registrants are women and $49.5 \%$ are men.

- In terms of age structure, the largest share of enrolments is in the 26 - 45 age 
group (49\%). The lowest share is in the 45 - 60 age group (25\%).

The methodology and technique of mapping and visualization used in this study can be very useful, if applied to the other different electoral variables, especially those relating to results.

\section{Conflicts of Interest}

The author declares no conflicts of interest regarding the publication of this paper.

\section{References}

Beauguitte, L., \& Lambert, N. (2015). L’HyperAtlas électoral parisien (2007-2012). Un outil pour l'analyse des dynamiques électorales intra-urbaines. https://mappemonde-archive.mgm.fr/num42/articles/art14201.html

Belarem, M. (2017). Cartographie multiscalaire des élections tunisiennes de 2011. In Revue du CERES No. 3. Série Cartographie (pp. 91+106). Tunis.

Belhedi, A. (1992a). Société, espace et développement en Tunisie (262 p.) Tunis: Publication Université de Tunis.

Belhedi, A. (1992b). L'organisation de l'espace en Tunisie. Tunis: Publication Université de.

Belhedi, A. (2005). La dynamique économique régionale en Tunisie. Analyse structurelle résiduelle. Cybergeo, No. 310,1-17. http://cybergeo.revues.org/3376

https://doi.org/10.4000/cybergeo.3376

Ben Fguira, S., \& Belarem, M. (2018). Quel avenir pour le logement social en Tunisie? http://journals.openedition.org/confins/13450 https://doi.org/10.4000/confins.13450

Benoit Le, R. (2011). Cartographie et analyse territoriale multiscalaire. Réingénierie des logiciels HyperAtlas et HyperAdmin. Vision par ordinateur et reconnaissance de formes.

Chouari, W., \& Belarem, M. (2016). Enjeux de la Tunisie orientale: un territoire développé et un environnement à protéger.

http://journals.openedition.org/confins/11701

Delwit, P. (2019). Radical Right-Wing Parties Facing the Wall of the Local? The Vlaams Belang and Local Elections (1982-2018). Open Journal of Political Science, 9, 631-651. https://doi.org/10.4236/ojps.2019.94039

Dhieb, M. B., Mabrouk, B. M., \& Belhaj Ali, A. (2015). Building the Tunisian Toponymic Geodatabase. Rio de Janeiro, Brazil: 27th International Cartographic Conference, 16th General Assembly. https://icaci.org/files/documents/ICC_proceedings/ICC2015/papers/38/712.html

Dhieb, M., \& Belarem, M. (2016). Le découpage administratif tunisien: Entre enjeux politique et administratif et représentation citoyenne. In Colloque International: Maillages territoriaux, Démocratie et Élection (pp. 30-38).

http://riate.cnrs.fr/wp-content/uploads/2017/01/Actes-de-conf\%C3\%A9rence_Monasti r2016_VF_090117.pdf

Franklin, M. (1992b). The Decline of Cleavage Politics. In M. Franklin, T. Mackie, H. Valen (Eds.), Electoral Change: Response to Evolving Social and Attitudinal Structure in Western Countries (pp. 383-405). Cambridge: Cambridge University Press.

Franklin, M., Mackie, T., \& Valen, H. (1992a). Electoral Change: Response to Evolving 
Social and Attitudinal Structure in Western Countries. Cambridge: Cambridge University Press.

Gana, A. (2011). Les inégalités socio-territoriales aux origines de la révolution tunisienne: Défis du développement, enjeux pour la recherche, Lettre de L'IRMC. Bulletin trimestriel, No. 6, 19-20.

Gana, A., \& Van Hamme, G. (2016). Elections et territoires en Tunisie. Enseignements des scrutins post-révolution (2011-2014). Karthala.

Gana, A., Van Hamme, G., \& Ben Rebah, M. (2012). Géographie électorale et disparités socio-territoriales: Les enseignements des élections pour l'assemblée constituante en Tunisie. L'Espace Politique. http://journals.openedition.org/espacepolitique/2486 https://doi.org/10.4000/espacepolitique.2486

Ysebaert, R., Lambert, N., Grasland, C., Le Rubrus, B., Villanova-Oliver, M., Gensel, J., \& Plumejeaud, C. (2011). HyperAtlas, un outil scientifique au service du débat politique-Application à la politique de cohésion de l'Union Européenne (pp. 1-32). Paris, France: 1er Congrès du Collège International des Sciences du Territoire (Paris).

http://hypercarte.imag.fr

http://hypercarte.imag.fr/hypercarte_userManual

http://www.ins.nat.tn

http://www.isie.tn 